Revista Perspectivas Online: Exatas \& Engenharias Anais do V Seminário P\&D PROVIC/PIBIC II Encontro de Iniciação Científica CNPq Vol. 10, $\mathrm{n}^{\circ}$ 29, Suplemento, 2020

\title{
Políticas públicas e saneamento básico: aspectos legais para a implementação dos serviços
}

\author{
Camille Pereira de Oliveira ${ }^{1}$, Jhonny Lacerda ${ }^{2}$, Frank Pavan de Souza ${ }^{3}$ \\ (1) Aluna de Iniciação Científica do PIBIC/ISECENSA - Curso Engenharia Civil; (2) Aluno de Iniciação Científica do PIBIC/CNPq - Curso Engenharia Civil; \\ (3) Pesquisador Orientador - Laboratório de Pesquisa em Gestão e Tecnologias na Construção Civil - GETECC - Curso de Engenharia Civil- Institutos \\ Superiores de Ensino do CENSA - ISECENSA, Rua Salvador Correa, 139, Centro, Campos dos Goytacazes, RJ, Brasil
}

De acordo com a Constituição da República Federativa do Brasil de 1988, todo cidadão tem direito a prestação de serviços públicos, para a garantia da qualidade de vida. Entre os serviços estabelecidos pela Carta Magna estão àqueles previstos no campo do saneamento básico, mais precisamente o de abastecimento de água tratada, a coleta e o tratamento de esgoto, o manejo e a gestão de resíduos sólidos urbanos e a gestão de águas pluviais, que compõem as diretrizes do saneamento básico no país. Contudo, verifica-se que parte da população não possui acesso universal a todos os serviços, fato que pode acarretar o desencadeamento de doenças. Dados disponibilizados pelo o Ministério da Saúde revelam que no ano de 2017 foram registrados 2.340 óbitos, decorrentes de doenças de veiculação hídrica. Neste sentido, esta pesquisa teve como objetivo, realizar um diagnóstico acerca dos aspectos legais relacionados às políticas públicas, tendo como pano de fundo os serviços de saneamento. A pesquisa classifica-se como básica, uma vez que se utilizou de bases teóricas para o seu desenvolvimento. Quanto aos objetivos classifica-se como exploratória, pois foi estruturada na identificação de aspectos legais vigentes relacionados ao tema. Por fim classifica-se como documental, uma vez que não foram utilizados elementos analíticos, mas da lei seca em si. Para a realização da pesquisa foram realizadas incursões digitais junto aos sites oficiais do governo, no diário oficial e na literatura específica. Assim foi possível diagnosticar o arcabouço legal de políticas públicas, que pode ter relação direta e indireta com os serviços de saneamento básico no país. Foi possível constatar que o Brasil dispõe de um ordenamento jurídico coeso, no que tange ao saneamento básico. Neste sentido cabe aqui citar: Lei $\mathrm{n}^{\mathrm{o}}$ 11.445/2007 (Dispõe sobre o Plano Nacional do Saneamento - PLANSAB); Lei n 9.433/1997 (Dispõe sobre a Política Nacional de Recursos Hídricos; Lei n 10.251/2010 (Dispõe sobre o Estatuto da Cidade); Lei $n^{\circ}$ 13.089/2015 (Dispõe sobre o Estatuto da Metrópole). É importante ressaltar, que há um Projeto de Lei (PL nº 3.261/2019) em posse do Presidente da República, para ser sancionado e que dispõe sobre alterações no PLANSAB. Assim, pôde-se concluir que o fato das leis terem sido promulgadas em períodos distintos, com apartamento de datas, pode ter gerado complexidade na sua aplicação. Ademais, concluiu-se que apesar das políticas públicas exigirem participação social, na elaboração e execução de seus instrumentos, não é possível perceber engajamento efetivo da sociedade, principalmente, por falta de motivação por parte do poder público ou incentivo popular. Espera-se ao final, que possa haver maior aproximação entre o poder público e a sociedade civil, com vistas a integração das políticas públicas e consequentemente a melhoria da qualidade de vida.

Palavras-chave: Políticas Públicas. Saneamento. Qualidade de Vida.

Agência Financiadora: ISECENSA, CNPq. 